\title{
Mini-cutting of Plathymenia reticulata benth. with mini- stumps conducted in suspended seedbed and tubes
}

Giovanna Campos Mamede Weiss de Carvalho ${ }^{1 * i \mathrm{D}}$, David Siqueira Pessanha ${ }^{1 \mathrm{iD}}$, Renata de Deus da Silva ${ }^{1 \mathrm{iD}}$, Maria Kalyane Farias da Silva ${ }^{\mathrm{iD}}$, Deborah Guerra Barroso ${ }^{\mathrm{1iD}}$

${ }^{1}$ State University of the North Fluminense Darcy Ribeiro, Campos dos Goytacazes, Rio de Janeiro, Brazil

SILVICULTURE

\section{ABSTRACT}

Background: Despite the importance of Plathymenia reticulata for forestry and ecological purposes, a protocol for the vegetative propagation of the species remains unclear mainly due to the low adventitious rooting of the propagules of the species. In this sense, this work aimed to evaluate the rooting of minicuttings of juvenile materials of $P$. reticulata and our hypothesis: (1) maintaining propagules under mist chamber for different periods affects the rooting process; (2) the mini-stump management system due to the restriction of the root system affects the production of mini-cuttings and the quality of clonal seedlings.

Results: It was not necessary for more than 30 days in a mist chamber to induce rooting. The highest percentage of rooting was obtained 50 days after staking. Mini-gardens set up in suspended seed bed and tubes $\left(280 \mathrm{~cm}^{3}\right)$ had the average mini-cuttings productivity of 4.32 and 2.06 , respectively, over 270 days of exploration (monthly collections). At 120 days after staking, there was no difference in the survival and in the final quality of clonal seedlings produced. However, clonal seedlings from minigarden in tubes had higher height, leaf area, and number of first-order roots. Regardless of the minigarden management, the clonal seedling production index was 50\%.

Conclusion: We can conclude that $P$. reticulata seedling production via mini-cutting technique is possible.

Keywords: Adventitious rooting, Cloning, Native forest species, Vegetative propagation

\section{HIGHLIGHTS}

It is not necessary more that 30 days in a mist chamber to P. reticulata rooting.

The suspended seed bed mini-garden showed the highest production of mini-cuttings.

The root restriction of mini-stumps didn't affect the quality of the clonal seedlings.

The clonal seedling production rate for both types of mini-gardens was $50 \%$.

CARVALHO, G. C. M W.; PESSANHA, D. S.; SILVA, R. D.; SILVA, M. K. F.; BARROSO, D. G. Mini-cutting of Plathymenia reticulata benth. with mini-stumps conducted in suspended seed bed and tubes. CERNE, v. 27, e-102584, doi: 10.1590/01047760202127012584 


\section{INTRODUCTION}

Plathymenia reticulata Benth. is a tropical forest species of the Fabaceae family. The species is spread throughout the Brazilian states, occurring in the Amazon, Cerrado, Caatinga, and Atlantic Forest biomes (Flora do Brasil, 2020; Freire et al., 2017). The species has presented high survival rates and growth after outplanting (Barroso et al, 2018), and its timber is valuable due to its high quality, ease of handling, and resistance to xylophagous organisms, qualities that ensure the importance of this species (Lorenzi, 2002; Carvalho, 2009).

$P$. reticulata seedling production is mostly carried out using seeds. However, Pessanha et al. (2018) reported that matrices have shown irregular behavior in seed production. Another drawback to the use of sexual propagation involves the implantation of heterogeneous stands, an outcome that increases costs related to management practices and harvesting. In this sense, the vegetative propagation of the species has the advantage of creating homogenous plantations.

Among the vegetative propagation techniques applied to forest species, mini-cutting has been used on a commercial scale for the production of Eucalyptus spp. and Toona ciliata seedlings (Bela Vista Florestal, 2020). However, the results of various studies indicate the technique is feasible for other species, including Cedrela fisillis (Xavier et al., 2003), Ilex paraguariensis (Wendling et al., 2007), Erythrina falcata (Cunha et al., 2008), Calophyllum brasiliense (Kalil Filho et al., 2010; Silva et al., 2010; Santos, 2013; Ciriello and Mori, 2015), Cariniana legalis (Gatti et al., 2011), Anadenanthera colubrina (Dias et al., 2012), Handroanthus heptaphyllus (Oliveira et al., 2015; Oliveira et al., 2016), Lecythis pisonis (Santana, 2017), Inga edulis (Berude et al., 2019), and Cabralea canjerana (Burin et al., 2018a and 2018b).

Several factors can drive the rooting process (jointly or independently) such as humidity, temperature, light, substrate, genotype, physiological and nutritional conditions, age of the mother plant, size and type of propagule, presence of leaves, and collection time (Xavier et al., 2003b). In this context, the period during which a propagule remains in each phase (e.g. mist chamber and shade house) may influence root survival rates (Ferreira et al., 2004).

The growth conditions to which the mini-stumps are submitted may also influence sprouting capacity and root quality (Wendling et al., 2005; Souza Junior, 2007; Cunha et al., 2008; Silva et al., 2012; Souza et al., 2014b). For P. reticulata, the low adventitious rooting rates reported by Neubert et al. (2017), Pessanha et al. (2018), and Rodrigues (2018) may have discouraged seedling production with this technique. Studies investigating stepwise and management of the process are needed in order to enhance understanding of the main factors driving $P$. reticulata rooting.

Thus, this work aimed to evaluate whether increasing the time $P$. reticulata mini-cuttings remain in the rooting sector (mist chamber) results in improved rooting and to help establish the ideal time mini-cuttings should remain in this sector. It also aimed to verify if root system restriction influences the quality of the clonal seedlings.

\section{MATERIAL AND METHODS}

The study was carried out in a greenhouse covered with plastic $(150 \mu \mathrm{m})$ at the Universidade Federal do Norte Fluminense Darcy Ribeiro - UENF, within the municipal limits of Campos dos Goytacazes, RJ, Brazil (21 $11^{\circ} 23^{\prime \prime} \mathrm{S}$ and $41^{\circ}$ $19^{\prime} 41^{\prime \prime}$ W). The experimental scheme is presented in Fig.1. In the rooting sector, using data logger model RHT10 (Extech Instruments), with readings programmed every hour, the average maximum and minimum temperature were 26.9 and $19.4^{\circ} \mathrm{C}$, respectively, while the average maximum and minimum humidity were 87.3 and $52.6 \%$, respectively.

\section{Experiment 1 - Time in mist chamber}

The mini-cuttings were collected from a seminal mini-garden, and each mini-cutting was $6 \mathrm{~cm}$ in length. One pair of leaves was retained on each mini-cutting with the leaflets trimmed $50 \%$ to reduce the umbrella effect, which prevents water from reaching the substrate. Then 430 mini-cuttings were staked in tubes of $120 \mathrm{~cm}^{3}$ filled with substrate composed of pine bark, coconut fiber, peat fiber, and vermiculite. We added $8 \mathrm{~g}$ of slow-release fertilizer (N P $\mathrm{K}-15-9-12)$ per $\mathrm{kg}^{-1}$ of the substrate.

The mini-cuttings were sent to an intermittent mist chamber (rooting sector) covered with $150 \mu \mathrm{m}$ polypropylene plastic, 30\% nylon screen (Sombrite), and aluminized screen (Aluminet - 30\% shading). The mist flow was $3 \mathrm{~mL} \mathrm{~min}^{-1} \mathrm{~m}^{-2}$ and the nebulization frequency approximately every 20 minutes for 30 seconds. After 30 days in the rooting sector the survival rate was $66.5 \%$ (286 mini-cuttings). The dead mini-cuttings were discarded and 40 of the surviving cuttings were randomly selected (10 mini-cuttings per plot) for rooting assessment.

Then, 50\% (120 mini-cuttings) of the surviving mini-cuttings were then moved to a greenhouse with a plastic cover (150 $\mu \mathrm{m}$ agricultural film) and 30\% nylon screen (Sombrite) and automatic sprinkler with irrigation three times a day for approximately 8-10 minutes. In the greenhouse the mini-cuttings were arranged in a completely randomized design with 12 plots and 10 mini-cuttings per plot with 4 repetitions per treatment. The mini-cuttings that remained in the rooting sector were subjected to the same experimental design and sampling procedure. The rooting assessments, for both environments, were carried out every ten days up to 60 days after staking and 4 plots (40 minicuttings) were randomly removed at each time.

For each rooting assessment, after washing the root system under tap water we evaluated the presence of calluses and the number and length of first order roots (NFOR and LFOR). We considered rooted mini-cuttings those possessing at least one root greater than $0.2 \mathrm{~mm}$. The samples were subsequently oven-dried at $65^{\circ} \mathrm{C} \pm 2$ for $72 \mathrm{~h}$ and weighed to determine the dry mass of the roots (DMR).

For data analysis, a completely randomized design under a $2 \times 3$ factorial scheme was used. The environmental conditions (mist chamber and greenhouse) were considered the main factor and the subplot factor was the assessment time $(40,50$, and 60 days). The mini-cuttings removed 30 


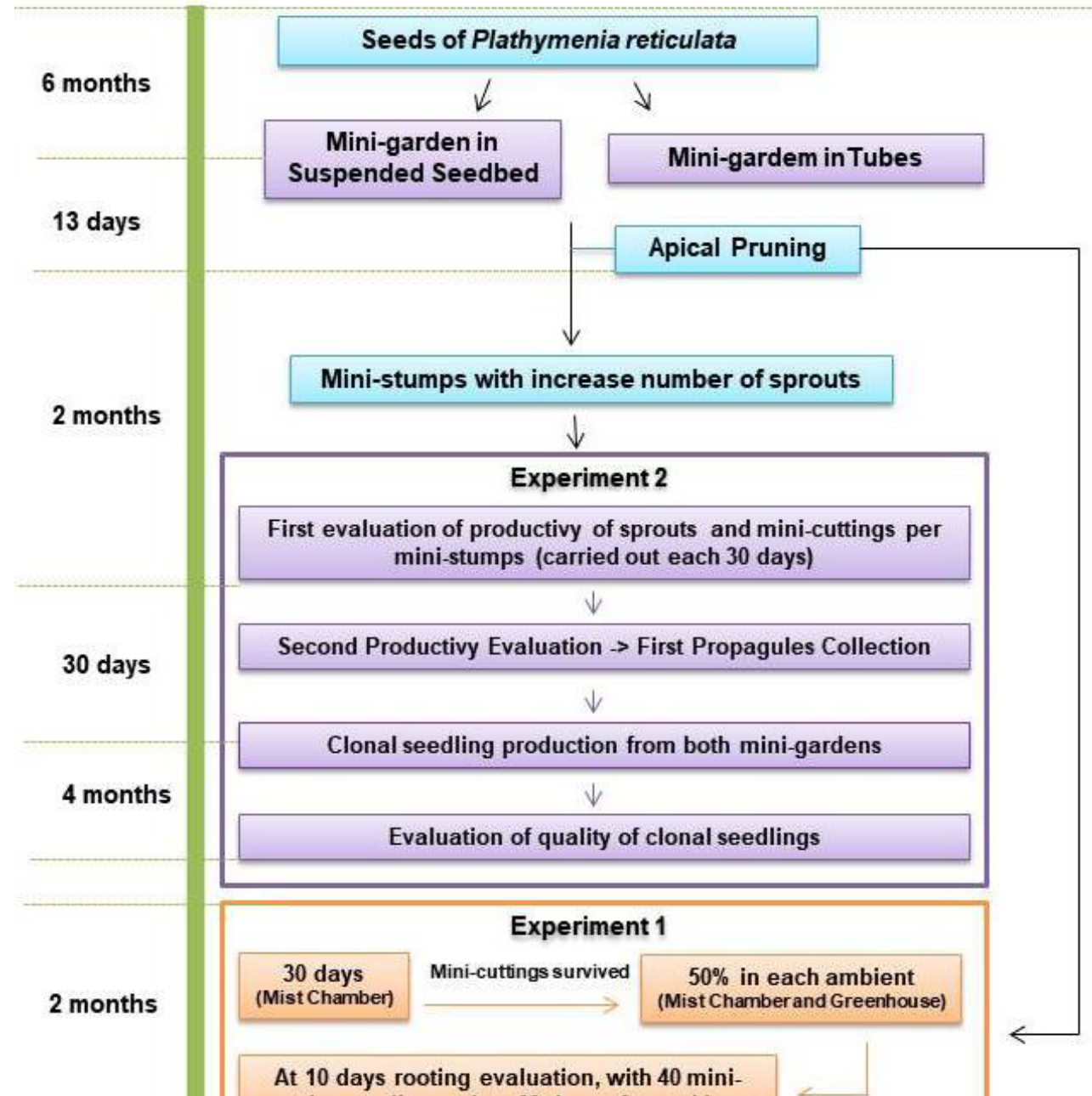

Fig. 1 Flowchart of experimental procedure for assessing the vegetative propagation of Plathymenia reticulata with the mini-cutting technique.

days after staking were considered an additional treatment with 4 replicates and 10 mini-cuttings per plot. Then, twoway ANOVA and Tukey tests $(p<0.05)$ were performed to test for the individual and interactive effects of the treatments (main factor and subplot factor) - agricolae package, Mendiburu, (2019) through R environment ( $R$ Core Team, 2019).

\section{Experiment 2 - Mini-garden management and clonal seedling production}

Two mini-gardens treatments were established: (1) 36 mini-stumps in suspended seedbeds and (2) 36 ministumps in tubes $(180 \mathrm{~cm} 3)$. The seedbed sizes were $113 \times 105$ x $28 \mathrm{~cm}$ (length, width, and height, respectively), and the mini-stumps were spaced at $17 \times 18 \mathrm{~cm}$. The substrate for the seedbed was composed of an $8 \mathrm{~cm}$ layer of sand below a $20 \mathrm{~cm}$ layer containing a mixture of pine bark substrate, coconut fiber, and 2:1:1 organic fertilizer along with 600 $\mathrm{g}$ of simple superphosphate. Then the seedlings of both treatments had their apices pruned $10 \mathrm{~cm}$ from the base to form the mini-stumps.
Nitrogen fertilization was performed twice in the mini-gardens, 120 and 210 days after mini-stump formation. The solution was prepared according to Gonçalves and Benedetti (2005) with $12 \mathrm{~g}$.L $\mathrm{L}^{-1}$ of $\left(\mathrm{NH}_{4}\right) 2 \mathrm{SO}_{4^{\prime}} 10 \mathrm{~mL}$ per mini-stump. Mini-garden productivity for each treatment was measured monthly up to 270 days after mini-stump establishment, assessing the number of sprouts and minicuttings produced per mini-stump.

In the second productivity assessment, $8 \mathrm{~cm}$ long mini-cuttings containing a pair of leaves with the leaflets trimmed by $50 \%$ were detached. The mini-cuttings were staked in $180 \mathrm{~cm}^{3}$ tubes filled with pine bark substrate, coconut fiber, peat fiber, and vermiculite and slow release fertilizer (N P K - 15-9-12, with $8 \mathrm{~g}$ applied per $\mathrm{Kg}^{-1}$ of the substrate). Each mini-garden treatment had 8 replicates with 18 plants in a completely randomized design. The trays with the mini-cuttings were sent to the rooting sector, where they remained for 30 days before being sent to the greenhouse.

$D Q I=\frac{T D M}{\left(\frac{H}{D}\right)+\left(\frac{D M A P}{D M S R}\right)}$ 
The surviving clonal seedlings were evaluated for height $(\mathrm{H})$ and stem diameter (D) 120 days after staking. Next, we measured leaf area using a bench area meter ( $\mathrm{LI}$ - 3000 LI-COR Inc) and the samples were oven-dried at $65^{\circ} \mathrm{C} \pm 2$ for $72 \mathrm{~h}$ to determine dry shoot mass (DMS). The root systems were then washed under tap water and callus presence, number of first order roots (NFOR), number of first order roots with branches (NRB), and the length of first order roots (LFOR) were assessed.

The total length of the root system (TLR), root diameter (DR), and volume (VR) were also measured with Winrhizo software (Regent Instruments Inc., Quebec, Canada, 2000). Finally the root samples were oven-dried at $65^{\circ} \mathrm{C} \pm 2$ for $72 \mathrm{~h}$ to determine the dry mass of the root system (DMRS). We calculated the Dickson seedling quality index as described by Dickson et al. (1960) with the following equation: where TDM = total dry mass (g), DMS = shoot dry mass; DMSR = dry mass of root system (g); $\mathrm{H}=$ height $(\mathrm{cm})$; $\mathrm{D}=$ stem diameter $(\mathrm{mm})$.

Due to the high mini-cutting mortality during the experiment, the initial experimental design was modified. Thus, the surviving clonal seedlings from each mini-garden treatment were randomly redistributed for data analysis purposes with each treatment having 6 replicates with 12 plants in a completely randomized design.

Before proceeding to statistical analyses, quantitative data were converted into $\sqrt{x}+1$ and the percentage data into arcsine $\sqrt{ } x$ (Zimmermann, 2004). The other data were submitted to diagnostic plots (Residuals fitted, Normal, and Leverage - base package, R Core Team, 2019) and the maximum likelihood function test (Box-Cox) - MASS package, Venables and Ripley, (2002) and the data transformed in Log $(x+1)$. Next, one-way ANOVA and Tukey tests $(p<0.05)$ were performed for treatment comparison - agricolae package, Mendiburu, (2019). The number of mini-cuttings and shoots and the number of accumulated mini-cuttings were submitted to descriptive analyses by confidence interval.

\section{RESULTS}

\section{Experiment 1- Time under mist chamber}

The survival rate of mini-cuttings was $67 \%$ after 30 days in the rooting sector under intermittent misting. In the subsequent assessments of the remaining clonal seedlings, arranged in the greenhouse, the survival rate was $70 \%$.

The highest percentage of $P$. reticulata rooting was observed 50 days after staking, and the environmental factor did not affect the rooting of mini-cuttings (Tab.1). In addition, treatments showed an average of $44 \%$ of minicuttings with callus formation, regardless of root emission.
Tab. 1 Mini-cutting rooting of Plathymenia reticulata Benth. at different times in the mist chamber and greenhouse. $\mathrm{N}=40$.

\begin{tabular}{ccc}
\hline \multirow{2}{*}{$\begin{array}{c}\text { Time* } \\
\text { (days) }\end{array}$} & \multicolumn{2}{c}{ Rooting (\%) } \\
\cline { 2 - 3 } & Mist chamber & Greenhouse \\
\hline 40 & $0 \mathrm{bA}$ & $3 \mathrm{bA}$ \\
50 & $10 \mathrm{aA}$ & $20 \mathrm{aA}$ \\
60 & $15 \mathrm{abA}$ & $8 \mathrm{abA}$ \\
\hline
\end{tabular}

*Days after staking. The means with the same lowercase letter in the line and the same uppercase letter in the column did not differ, according to the Tukey test, with a $5 \%$ significance.

\section{Experiment 2 - Mini-garden management and clonal seedling production}

The consecutive mini-cutting collections did not significantly affect the survival of the mini-stumps in both mini-garden management schemes. The averages for the survival of mini-stumps in suspended seedbeds and tubes was $83.33 \%$ and $100 \%$, respectively, 270 days into the mini-gardens.

Mini-stumps in both types of mini-garden managements showed the ability and capacity to produce new shoots after each new sprout collection. However, there was a difference in the productivity of sprouts and minicuttings per mini-stump, as the mini-stumps established in tubes showed a higher number of sprouts. In contrast, the production of sprouts was the same in both mini-garden systems at 120,150, and 270 days after the formation of ministumps (Fig.2 A and B).

The suspended seedbed mini-garden had the highest production of mini-cuttings at the end of 270 days after the formation of mini-stumps (Fig. 3).

Regardless of the mini-garden management technique, the survival rate was $50 \%$ considering the initial number of mini-cuttings staked (144 mini-cuttings per treatment). Although there was no difference in the production of dry biomass, clonal seedlings produced by mini-cuttings from the tube mini-garden possessed higher heights $(\mathrm{H})$ and leaf area (LA) (Tab. 2).

Regarding the root system, there was a difference in the number of first order roots (NFOR) and the number of first order roots with branches (NRB) between the two minigarden systems. Greater height measurements resulted with mini-cuttings from mini-stumps established in tubes (Tab. 2). The Dickson Quality Index values did not differ between the types of mini-gardens.

\section{DISCUSSION}

\section{Experiment 1 - Time under mist chamber}

Low rooting performance of mini-cuttings may be linked to physiological conditions and environmental factors such as temperature and humidity in the rooting sector (Xavier et al., 2013). However, during the present experiment, the temperature and humidity conditions of the mist chamber were conducive to rooting. 
A
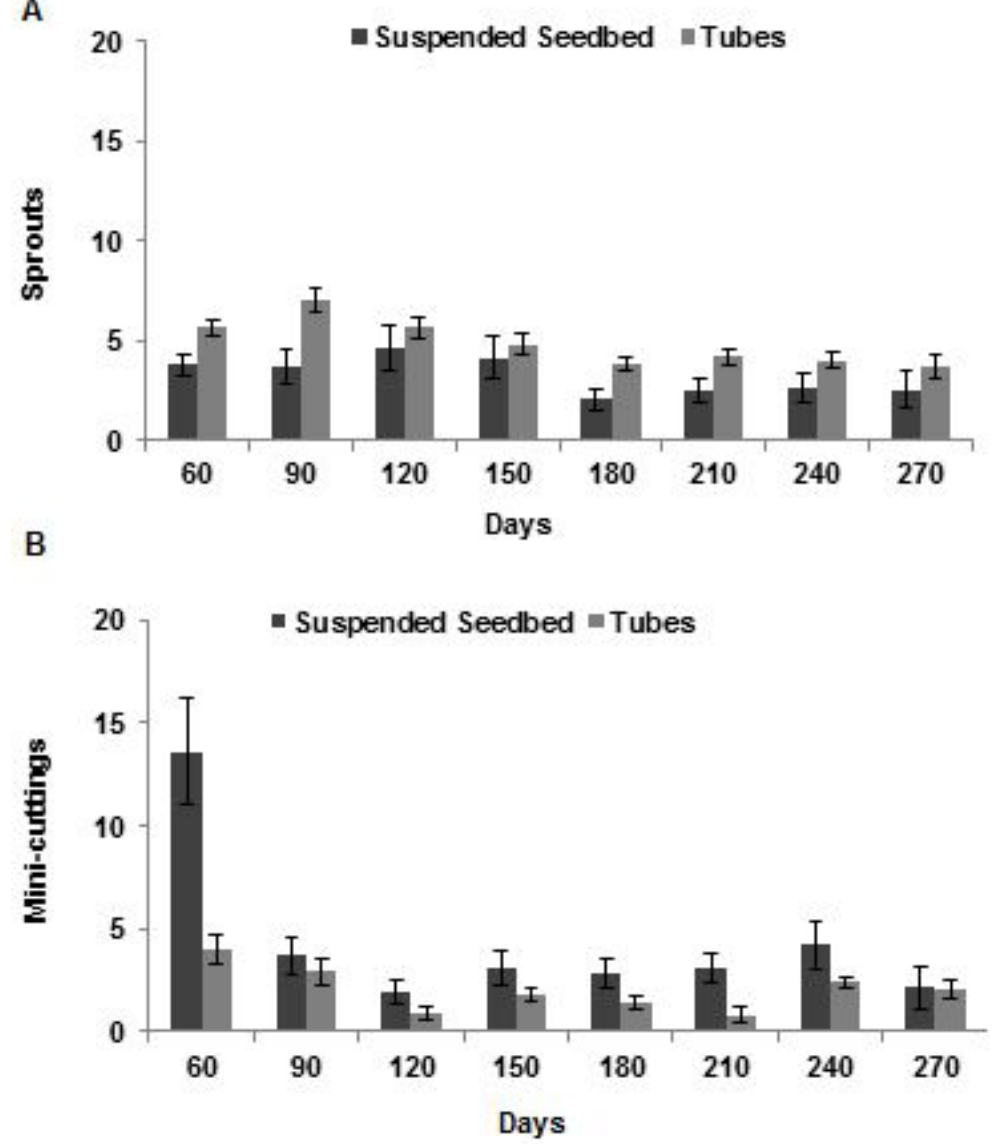

Fig. 2 Production of sprouts per ministump (A) and mini-cutting productivity per mini-stump (B) of Plathymenia reticulata Benth. carried out in two minigardens systems (suspended seedbed and tubes) for 270 days after the formation of mini-stumps, with successive collections of mini-cuttings every 30 days. $\mathrm{N}=36$. Bars represented $5 \%$ confidence interval.
While several studies have investigated vegetative propagation with the mini-cutting technique for $P$. reticulata, to our knowledge the literature lacks sufficiently robust and useful data that can be applied on a commercial scale. Rodrigues (2018) obtained $55.88 \%$ and $87.50 \%$ survival rates for apical and intermediate mini-cuttings, respectively, 45 days after staking. Without the application of plant growth regulators, Pessanha et al. (2018) reported that P. reticulata rooted $25.00,0.01$, and $8.33 \%$ in the collections carried out at 60,90, and 150 days after apical pruning of the mini-stumps, respectively. These results are similar to our findings. On the other hand, P. reticulata rooted 30 and $31 \%$ when the whole leaf remained intact and when reduced by $75 \%$, respectively (Neubert et al., 2017).

The process of callogenesis at the base of vegetative propagules may be an indicator of future rooting (Goulart et al., 2014). Once there is adventious rooting, there are two patterns of root system emergence: the direct, in which rooting occurs with the emergence of the root directly from the propagule, and the indirect, in which the emergence of the root follows the formation of the callus (Xavier et al., 2013). In order for this to occur, the propagules must be kept longer under conditions adequate for rooting development (Oliveira et al., 2012; Pimentel et al., 2019). In this sense, Silva (2019) reported that Paratecoma peroba

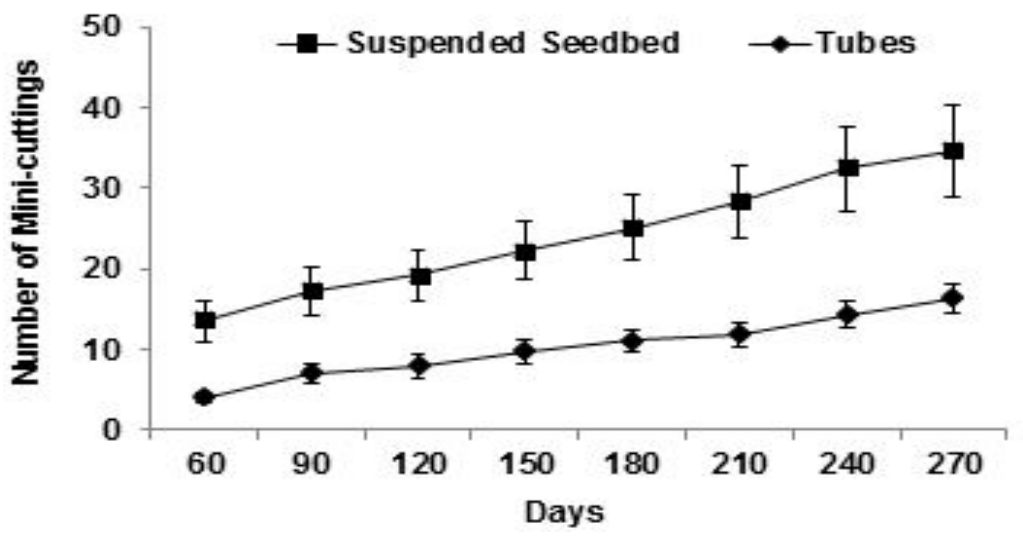

Fig. 3 Accumulated production of minicuttings with mini-stumps of Plathymenia reticulata Benth. carried out in two minigardens systems (suspended seedbed and tubes), 270 days after the formation of ministumps, with successive collections of minicuttings every 30 days. $N=36$. Bars represent a $5 \%$ confidence interval. 
Tab. 2 Evaluation of Plathymenia reticulata Benth. clonal seedlings, produced with the mini-cutting technique from propagules obtained in mini-stumps carried out in suspended seedbeds and tubes 120 days after staking.

\begin{tabular}{lcrl}
\hline \multirow{2}{*}{ Variables } & \multicolumn{2}{c}{ Mini-garden } & \multirow{2}{*}{ CV (\%) } \\
\cline { 2 - 3 } & Suspended Seedbed & Tubes & \\
\hline H $(\mathrm{cm})$ & $8.87 \mathrm{~b}$ & $11.86 \mathrm{a}$ & 46.79 \\
D $(\mathrm{mm})$ & $2.69 \mathrm{a}$ & $1.87 \mathrm{~b}$ & 31.68 \\
LA $\left(\mathrm{cm}^{2}\right)$ & $35.15 \mathrm{~b}$ & $65.64 \mathrm{a}$ & 32.11 \\
DMS $(\mathrm{g})$ & $0.39 \mathrm{a}$ & $0.48 \mathrm{a}$ & 55.25 \\
DMSR $(\mathrm{g})$ & $0.10 \mathrm{a}$ & $0.13 \mathrm{a}$ & 82.88 \\
NFOR & $3.33 \mathrm{~b}$ & $4.63 \mathrm{a}$ & 24.05 \\
NRB & $2.85 \mathrm{~b}$ & $3.90 \mathrm{a}$ & 24.99 \\
LFOR $(\mathrm{cm})$ & $9.74 \mathrm{a}$ & $8.97 \mathrm{a}$ & 23.36 \\
TLR $(\mathrm{cm})$ & $318.74 \mathrm{a}$ & $464.71 \mathrm{a}$ & 29.35 \\
DR $(\mathrm{mm})$ & $0.47 \mathrm{a}$ & $0.42 \mathrm{~b}$ & 27.90 \\
VR $\left(\mathrm{cm}^{3}\right)$ & $0.54 \mathrm{a}$ & $0.68 \mathrm{a}$ & 64.81 \\
DQI & $0.053 \mathrm{a}$ & $0.056 \mathrm{a}$ & 74.60 \\
\hline
\end{tabular}

adventitious rooting started after intense callus formation at the base of the mini-cuttings. The author found that $90 \%$ of the mini-cuttings had calluses, and roots were observed only 40 days after staking.

Callus formation at the base of mini-cuttings was also observed in other forest species. For Aniba Rosaeodora, $26.66 \%$ of the vegetative propagules presented calluses (Menezes et al., 2018). For llex paraguariensis, $44.14 \%$ and $47.72 \%$ of mini-cuttings presented calluses, without and with auxin application (2000 mg.L-1 of IBA), respectively (Pimentel et al., 2019).

\section{Experiment 2 - Mini-garden management and clonal seedling production}

The percentage of surviving $P$. reticulata ministumps was superior to that found in the literature for this species. 210 days after the establishment of a multiclonal mini-garden in tubes with seminal mini-stumps from 11 different matrices, Pessanha et al. (2018) found that only 8 progenies survived and the highest survival rate was 65\%. For the same species, Neubert et al. (2017) observed mortality of mini-stumps beginning in the second collection of mini-cuttings. In the fourth and last collections, the highest percentage of mini-stump survival reported by the authors was $64.58 \%$.

P. reticulata mini-stump survival rate variation among studies may be due to the genetic characteristics of the propagules, since neither nutritional nor water deficit issues of the mini-stumps were reported by the authors, nor were they observed in the present study during the course of the experiment.

On the other hand, the percentage of surviving $\mathrm{P}$. reticulata mini-stumps was similar to that found for other native forest species, such as Cedrela fissilis, whose that the mini-garden had a survival rate of $100 \%$ after four months of sprout collection (Xavier et al., 2003). Likewise, Oliveira et al. (2015b) observed a survival rate of $100 \%$ in Handroanthus heptaphyllus mini-stumps after 8 monthly collections.

The greater mini-cutting productivity when managed in suspended seedbeds might be explained by the area available for root growth. In contrast, irrigation and fertilization must be performed more often when using tubes due to their reduced volume (Silva et al., 2012; Wendling et al., 2005; Silva et al., 2012; Souza et al., 2015). This means that the lower the volume of the substrate, the higher the risk of nutritional deficiency, which can decrease mini-cuttings productivity.

When comparing two management systems in the formation of the clonal mini-garden (hydroponic system and in tubes) of Erythrina falcata, Cunha et al. (2008) found an average productivity of 2.9 mini-cuttings/mini-stump/ collection for suspended seedbed and 1.3 for tubes (110 $\mathrm{cm}^{3}$ ) in four collections within 15 days. Oliveira et al. (2015), studying the mini-cuttings of Handroanthus heptaphyllus five months after the first pruning of mini-stumps managed in tubes $\left(280 \mathrm{~cm}^{3}\right)$, obtained a production of 1.47 minicuttings/mini-stump. For Myracrodruon urundeuva ministumps in plastic tubes with a capacity of $1,550 \mathrm{~cm}^{3}$, the average productivity was 1.7 mini-cuttings/mini-stump over nine collections with intervals of 28 days (Justino et al., 2017). These findings indicate that the productivity of $P$. reticulata mini-stumps was similar to that observed for other native forest species.

Pessanha et al. (2018) used $P$. reticulata mini-cuttings $5 \mathrm{~cm}$ in length and the superior rate of cloned seedlings was $46.43 \%$. Thus, the higher index of $P$. reticulata clonal seedling production (50\%) found in the present study may be related to the size of the propagule, since shorter propagules may not have the necessary reserves for rooting and survival (Fachinello et al., 2005; Braga et al., 2006; Costa, Pinto and Bertolucci, 2007).

On the other hand, the larger the propagule, the greater the amount of carbohydrate reserves used as a carbon source for nucleic acid and protein biosynthesis (Fachinello et al., 1995). However, very long propagules may be more susceptible to dehydration due to their larger exposed surface areas that therefore require larger quantities of water to supply the greater amount of living tissue (Lima et al., 2006). However, Rodrigues (2018) used mini-cuttings of $P$. reticulata with $15 \mathrm{~cm}$ in length and observed lower percentages of propagule survival (13.33\% for apical mini-cuttings, $18.33 \%$ for intermediate, and $16.67 \%$ for basal, $N=60$ ).

Araújo et al. (2019), working with Paratecoma peroba mini-cuttings, found that $10 \mathrm{~cm}$ apical mini-cuttings showed the greatest survival (90\%) and rooting (80\%) rates, compared to shorter mini-cuttings, 90 days after staking. However, in the seedling production of Azadirachta indica by mini-cutting, Fernandes et al. (2017), using three sizes of mini-cuttings $(5,8$, and $11 \mathrm{~cm})$, observed that the size of the propagules did not affect rooting, although seedlings produced from mini-cuttings of greater length showed higher Dickson Quality Index (DQI) values.

The highest rooting percentages in propagules of greater lengths were also observed for Spondias tuberosa 
(Rios et al., 2012), Hibiscus rosa-sinensis L. (Pizzatto et al., 2011), and Ficus enormis (Mireski et al., 2019) cuttings.

However, for vegetative propagules of Piper umbellatum L. (Gomes and Krinski, 2016) and /lex paraguariensis (Pimentel et al., 2020), the size did not influence the survival or the rooting of the propagules. Thus it is reasonable to conclude that the propagule size response with respect to rooting and survival varies according to the species.

Factors such as temperature and humidity, both in the rooting sector and in the greenhouse, can also affect the survival and rooting rates of mini-cuttings (Brondani, 2008; Xavier et al., 2013). According to reports in the literature concerning several forest species, while the ideal temperature for the rooting sector is between 20 and $30^{\circ} \mathrm{C}$, the relative humidity should be at least $80 \%$ (Xavier et al., 2003; Brondani et al., 2007; Lamônica, 2013; Dias et al., 2015; Oliveira et al., 2016; Berude, 2018; Burin et al., 2018 a and; Rodrigues, 2018; Somavila, 2018; Souza, 2019). These values are similar to those observed in the present work and other works related to the vegetative propagation of $P$. reticulata (Neubert et al., 2017; Pessanha et al., 2018; Rodrigues, 2018). Therefore, temperature and humidity were not factors that led to the greater survival rate of the minicuttings in the present study.

The values regarding $H, D$, and DMS, observed in the present work are consistent with those found by Pessanha et al. (2018) for $P$. reticulata from the first sprout collection (60 days after the apical pruning of the ministump) five months after the staking of mini-cuttings. However, the values for these variables are lower than those the same authors obtained in later collections. In this way, there may be an improvement in the quality of the clonal seedlings in the present work with the use of propagules obtained during the execution of the minigarden, as observed by Pessanha et al. (2018).

Differences observed between the number of first-order roots of the mini-cuttings between the ministumps management systems were also observed by Silva et al. (2012). Those authors found that Toona ciliata clonal seedlings originating from mini-cuttings from mini-stumps established in tubes $\left(180 \mathrm{~cm}^{3}\right)$ had a greater number of roots in the rooting sector. They hypothesized that the mini-cuttings from suspended seedbeds incurred higher energy costs for maintaining leaf turgor, resulting in reduced investment in adventitious rooting.

$P$. reticulata root numbers in mini-cuttings from both mini-garden management schemes were lower when compared to those reported by Pessanha et al. (2018), who studied the same species. However, those same authors performed assessment 150 days after staking. These values are also lower than those found for other tropical forest species, such as Inga edulis, which reached 9.3 and 13.7 roots without and with the application of growth regulators (AIB: $8000 \mathrm{mg}^{\mathrm{kg}}{ }^{-1}$ ), respectively, 45 days after staking (Berude et al., 2019), Piptocarpha angustifolia mini-cuttings, showing 6.3 roots/mini-cuttings, collected in winter (Ferriani et al., 2011), and Cabralea canjerana mini-cuttings, which presented averages of 2.20 to 6.46 roots/mini-cuttings at the same collection time 60 days after staking (Burin et al., 2018). However, the values obtained for this variable were higher than those obtained for Eugenia involucrata mini-cuttings, which had 0.95 roots/mini-cuttings 120 days after staking (Chiele, 2016), and Aniba Rosaeodora minicuttings, which presented 2.08 roots / mini-cuttings 90 days after staking (Menezes et al., 2018).

The Dickson Quality Index (DQI) values obtained for mini-cuttings collected from both mini-gardens was the same. They were lower than those found by Pessanha et al. (2018) while working with the same species (DQI at 150 days after staking: 3.99).

These results indicate that the mini-cutting technique is a viable alternative to seedling production with P. reticulata, especially when seed sourcing is a constraining factor in the production process. However, further studies aiming to increase rooting rates and test other management factors driving the rooting process are required.

\section{CONCLUSION}

The time in the mist chamber did not affect the rooting percentages of the mini-cuttings; 30 days remains the recommended period. While mini-stump root restriction reduced the production capacity of mini-cuttings, it did not affect the clonal seedling production index and the final quality of the clonal seedlings.

\section{ACKNOWLEDGEMENT}

We thank the National Council for Scientific and Technological Development (CNPq) and the Carlos Chagas Filho Foundation for Research Support of the State of Rio de Janeiro (FAPERJ) for their financial support and scholarship.

\section{AUTHORSHIP CONTRIBUTION}

\author{
Project Idea:GCMWC, DGB \\ Funding: DGB \\ Processing: GCMWC, DSP, RDS, MKFS \\ Analysis: GCMWC, DSP, RDS, MKFS \\ Writing: GCMWC, DSP, DGB \\ Review: GCMWC, DSP, DGB
}

\section{REFERENCES}

ARAÚJO, E.; GIBSON, E. L.; SANTOS, A. R. D.; GONCALVES, E. D. O.; WENDLING I.; ALEXANDRE, R. S.; POLA, L. A. V. Mini-cutting technique for vegetative propagation of Paratecoma peroba. Cerne, v. 25, n. 3, p. 314-325, 2019.

BARROSO, D. G.; SOUZA, M. G. O. da S.; OLIVEIRA, T. P. de F. de; SIQUEIRA, D. P. Growth of atlantic forest trees and their influence on topsoil fertility in the southeastern Brazil. Cerne, v. 24, n. 4, p. 352-359, 2018.

BELA VISTA FLORESTAL. Cedro australiano. Disponível em https://www. belavistaflorestal.com.br/portfolio-item/mudas-de-cedroaustraliano/. Acesso em: 11 de dezembro de 2019.

BERUDE, M. C.; ARAÚJO, E. F.; SANT'ANA, B. T.; ALEXANDRE, R. S.; OLIVEIRA, E. G. de. Rooting of Inga edulis Mart.(Leguminosae-Mimosoideae) minicuttings. Floresta, v. 50, n. 1, p. 1091-1098, 2019. 
BRAGA, M. F.; SANTOS, E. C. D.; JUNQUEIRA, N. T. V.; SOUSA, A. A. T. C. D. FALEIRO, F. G.; REZENDE, L. N.; JUNQUEIRA, K. P. Enraizamento de estacas de três espécies silvestres de Passiflora. Revista Brasileira de Fruticultura, v. 28 n. 2, p. $284-288,2006$

BRONDANI, G. E.; WENDLING, I.; ARAUJO, M. A.; PIRES, P. P. Ácido indolbutírico em gel para o enraizamento de miniestacas de Eucalyptus benthamii Maiden \& Cambage x Eucalyptus dunnii Maiden. Scientia Agraria, v. 9, n. 2, p. $153-158,2008$

BRONDANI, G. E.; WENDLING, I.; BRONDANI, A. E.; ARAUJO, M. A.; SILVA, A L. L. D. GONÇALVES. A. N. Dynamics of adventitious rooting in minicutting of Eucalyptus benthamii x Eucalyptus dunnii. Acta Scientiarum, v. 34, n. 2 p. 169-178, 2012

BURIN, C.; BISOGNIN, D. A.; LENCINA, K. H.; GIMENES, E. S. Seleção precoce em Cabralea canjerana para a propagação por miniestaquia. Pesquisa Agropecuária Brasileira, v. 53, n. 9, p. 1018-1024, 2018 a.

BURIN, C.; ANTÔNIO BISOGNIN, D.; HAYGERT LENCINA, K.; SOMAVILLA, T. M.: PEDROSO, M. F. Enraizamento de miniestacas em diferentes épocas de coleta para a seleção de clones de canjerana Brazilian Journal of Agricultura Sciences/Revista Brasileira de Ciências Agrárias, v. 13, n. 2, p. 1-7, 2018 b.

CARVALHO, P. E. R. Espécies arbóreas brasileiras. Embrapa Informação Tecnológica, Colombo: Brasília, DF, v. 3, 2009, 11 p. Disponível em: https:// www infoteca.cnptia.embrapa.br/bitstream/doc/578666/1/CT231.pdf. Acesso em: 20 de janeiro de 2020.

CIRIELLO, E.; MORI, E. S. Rooting of guanandi (Calophyllum brasiliense CAMBESS) cuttings using indole-butyric acid. Cerne, v. 21, n. 4, p. 641-648, 2015

CHIELE, J. P. Época do ano, idade da planta matriz e concentrações de AIB no enraizamento de miniestacas de cerejeira-do-mato. 2016. 31 p. Trabalho de Conclusão de Curso Universidade Tecnológica Federal do Paraná - UTFPR.

COSTA, L. C. DO B.; PINTO, J. E. B. P.; BERTOLUCCI, S. K. V. Comprimento da estaca e tipo de substrato na propagação vegetativa de atroveran. Ciência Rural, v. 37, n. 4, p.1157- 1160, 2007

CUNHA, A. C. M. C. M. da; WENDLING, I.; SOUZA JÚNIOR, L. Miniestaquia em sistema de hidroponia e em tubetes de corticeira-do-mato. Ciência Florestal, v. 18, n. 1, p. 85-92, 2008.

DIAS, P. C.; XAVIER, A.; OLIVEIRA, L. S. de; PAIVA, H. N. de; CORREIA, A. C. G. Propagação vegetativa de progênies de meios-irmãos de angico-vermelho (Anadenanthera macrocarpa (Benth) Brenan) por miniestaquia. Revista Árvore v. 36, n. 3, p. 389-399, 2012.

DIAS, P. C.; XAVIER, A.; OLIVEIRA, L. S.; CORREA, A. C. G.; BARBOSA, G. A. Tipo de miniestaca e substrato na propagação vegetativa de angicovermelho (Anadenanthera macrocarpa (Benth.) Brenan). Ciência Florestal, v 25, n. 4, p. 909-919, 2015

DICKSON, A.; LEAF, A. L.; HOSNER, J. F. Quality appraisal of white spruce and white pine seedling stock in nurseries. Forest Chronicle, n. 36, p. 10-13, 1960

FACHINELLO, J. C.; HOFFMANN, A.; NACHTIGAL, J. C.; KERSTEN, E.; FORTES, G. R. de L. Propagação de plantas frutíferas de clima temperado. $2^{\mathrm{a}}$ edição Pelotas: Editora e Gráfica da UFPEL. 1995. 168 p.

FACHINELLO, J. C.; HOFFMANN, A.; NACHTIGAL, J. C. Propagação de plantas frutíferas. Embrapa Informações Tecnológicas. Brasília - DF. 2005. 221 p.

FERNANDES, S. P. dos S: ARRIEL, E. F. ARRIEL, D. A. A. MARTINS, K. B. da S. ALMEIDA, E. P. de; NOBREGA, A. M. F. da. Tamanho de miniestacas para produção de mudas de Azadirachta indica A. Juss. ACSA, v. 13, n. 4, p. 284-290, 2017.

FERRIANI, A. P.; ZUFFELLATO-RIBAS, K. C.; HELM, C. V.; BOZA, A.; WENDLING, I.; KOEHLER, H. S. Produção de brotações e enraizamento de miniestacas de Piptocarpha angustifolia. Pesquisa Florestal Brasileira, v. 31, n. 67, p. 257-264, 2011

FERREIRA, E. M.; ALFENAS, A. C.: MAFIA, R. G.; LEITE, H. G.; SARTORIO, R. C.; PENCHEL FILHO, R. M. Determinação do tempo ótimo do enraizamento de miniestacas de clones de Eucalyptus spp. Revista Árvore, v. 28, n. 2, p $183-187,2004$

FERREIRA, B. G. A.; ZUFFELLATO-RIBAS, K. C.; WENDLING, I.; KOEHLER, H. S.; NOGUEIRA, A. C. Miniestaquia de Sapium glandulatum (Vell.) Pax com o uso de ácido indolbutírico e ácido naftaleno acético. Ciência Florestal, v. 20 n. 1, p. 19-31, 2010.

FLORA DO BRASIL 2020. Plathymenia reticulata Benth. Disponivel em: http://floradobrasil.jbri.gov.br/reflora/listaBrasil/PrincipalUC/PrincipalUC. do\#CondicaoTaxonCP. Acesso em: 11 de dezembro de 2019.

FREIRE, M. J.; OLIVEIRA, L. M. DE; PIÑA-RODRIGUES, F. C. M. Vinhático (Plathymenia reticulata Benth.). Associação Brasileira de Tecnologia de sementes, Nota Técnica $n^{\circ} 1,2017$. Disponível em: https://www.abrates.org $\mathrm{br} /$ img/technical notes/bf9c5e59-6332-4055-b4ff-2cc17e20b395_Nota\%20 T\%C3\%A9cnica\%2001.pdf. Acesso em: 20 de novembro de 2019
GATTI, K. C.; GONÇALVES, R. de C.; XAVIER, A.; PAIVA, H. de. Propagação vegetativa de jequitibá Cariniana estrellensis (Raddi) por miniestaquia. Temas Agrarios, v.16, n. 2, p. $54-63,2011$.

GOULART, P. B.; XAVIER A.; IAREMA, L.; OTONI, W. C. Morfoanatomia da rizogênese adventícia em miniestacas de Eucalyptus grandis x Eucalyptus urophylla. Ciência Florestal, v.24, n.3, p. 521-532, 2014

GOMES, E. N.; KRINSKI, D. Propagação vegetativa de Piper umbellatum L. (Piperaceae) em função de substratos e comprimentos de estacas. Scientia Agraria, v. 17, n. 3, p. 31-37, 2016.

JUSTINO, S. T. P.; ARRIEL, E. F.; ARRIEL, D. A. A.; MORAIS, Y. Y. G. A.; Moraes Monte A. A de: SANTOS FËRANDES, S. P.' dos Sistema de manejo em minijardim clonal de Myracrodruon urundeuva Allemão. Agropecuária Científica no Semiárido, v. 13, n. 3, p. 255-263, 2017.

KALIL FILHO, A. N.; WENDLING, I.; FRANCISCON, L. Propagação vegetativa do guanandi por miniestaquia Embrapa Florestas-Comunicado Técnico (INFOTECA-E). 2010. 4 p

LIMA, R. D. L. S. D.; SIQUEIRA, D. L. D.; WEBER, O. B.; CAZETTA, J. O. Comprimento de estacas e parte do ramo na formação de mudas de aceroleira. Revista Brasileira de Fruticultura, v. 28, n. 1, p. 83-86, 2006

LORENZI, H. Árvores Brasileiras: Manual de Identificação e Cultivo de Plantas Arbóreas Nativas do Brasil. Nova Odessa: Plantarum, 4 ed, v.1. 2002.

MANTOVANI, N.; ROVEDA, M.; TRES, L.; FORTES, F. O.; GRANDO, M. F. Cultivo de Canafístula (Peltophorum dubium) em minijardim clonal e propagação por miniestacas. Ciência Florestal, v. 27, n. 1, p. 225-236, 2017.

MARANA, J. P.; MIGLIORANZA, E.; PONSECA, E. P. Qualidade de mudas de jaracatiá submetidas a diferentes períodos de sombreamento em viveiro. Revista Arvore, v. 39, n. 2, p. 275-282, 2015

MENDIBURU, F. agricolae: Statistical Procedures for Agricultural Research. R package version 1.3-1. 2019

MENEZES, A.; SAMPAIO, P. T. B.; BLIND, A. D. Propagação de pau-rosa (Aniba Rosaeodora Ducke) por estacas e miniestacas. Nucleus, v. 15, n. 1, p. 515-522, 2018

MIRESKI, M. C. DUARTE, M. M. STUEPP, C. A., \& WENDLING, I. Rooting of FiCUs enormis mini-cuttings with different lengths. Floresta, v.49, n. 4, p. 615-622 2019

MOURA, L. C.; TITON, M.; MOURA, C. C.; SOUZA, C. C.; SANTANA, R. C. Acido indolbutírico (AIB) e substratos na propagação vegetativa de Jatobá (Hymenaea courbaril L.) por miniestaquia. Advances in Forestry Science, v. 6 n. 1, p. 515-522, 2019

NAVROSKI, M. C.; ARAUJO, M. M.; REINIGER, L. R. S.; FIOR, C. S.; SCHFER, G. PEREIRA, M. O Initial growth of seedlings of Eucalyptus dunnii Maiden as influenced by the addition of natural polymer and farming substrats. Revista Árvore, v. 40, n. 4, p. 627-637, 2016.

NEUBERT V. D. F. XAVIER, A. PAIVA, H N. D. DIAS, P. C : GALLO R. Production of mini-cuttings and the influence of leaf reduction on rooting of vinhático (Plathymenia foliolosa Benth.). Revista Árvore, v. 41, n. 4, p. 1-9, 2017

OLIVEIRA, Y: ALCANTARA, G. B.; GUEDES, I.: PINTO, F.OUOIRIN, M.: BIASI, L A. Substratos concentraç̃es de ácido indolbutírico e tipos de miniestacas no enraizamento de melaleuca (Melaleuca alternifolia Cheel). Revista Brasileira de Plantas Medicinais, v. 14, n. 4, p. 611- 616, 2012.

OLIVEIRA, T. P. F; BARROSO, D. G: LAMŌNICA, K. R: CARNEIRO, J. G. A OLIVEIRA, M A Produtividade de minijardim multiclonal e enraizamento de miniestacas de Handroanthus heptaphyllus Mattos. Semina: Ciências Agrarias, v. 36, n. 4, p. 2423-2432, 2015 a.

OLIVEIRA, T. D. F; BARROSO, D G. LAMÔNICA, K R : CARNEIRO J D A OLIVEIRA, M. A. de. Productivity of polyclonal minigarden and rooting of Handroanthus heptaphyllus Mattos minicuttings. Semina: Ciências Agrárias, v. 36, n. (4), p. 2423-2432, 2015

OLIVEIRA, T. P. de F. de; BARROSO, D. G; LAMÔNICA, K. R.; CARAVALHO, G C. M. W. de. Application type and AIB minicuttings in seedling production of Handroanthus heptaphyllus Mattos. Ciência Florestal, v. 26, n. 1, p. 313-321, 2016

PESSANHA, S. E. G. L.; BARROSO, D. G.; BARROS, T. C., OLIVEIRA, T. P. de F. de; CARVALHO, G. C. M. W. de; CUNHA, M. da. Limitações na produção de vinhático (Plathymenia reticulata Benth) por miniestaquia. Ciência Florestal, v. 28, n. 4, p. 1688-1703, 2018

PEÑA, M. L.; ZANETTE, F.; BIASI, L. A. Miniestaquia a partir de minicepas originadas por enxertia de pitangueira adulta. Comunicata Scientiae, v. 6, n 3 , p. 397-306, 2015

PIMENTEL, N.; LENCINA, K. H.; KIELSE, P.; RODRIGUES, M. B.; SOMAVILLA, T. M; BISOGNIN D A Produtividade de minicepas e enraizamento de miniestacas de clones de erva-mate (Ilex paraquariensis A. St.-Hil.). Ciência Florestal, v. 29, n. 2 p. 559-570, 2019 . 
PIMENTEL, N.; GAZZANA, D.; SPANEVELLO, J. D. F.; LENCINA, K. H; BISOGNIN, D. A. Effect of mini-cutting size on adventitious rooting and morphophysiological quality of I/ex paraguariensis plantlets. Journal of Forestry Research, p. 1-8, 2020.

PIRES, P.; WENDLING, I.; AUER, C.; BRONDANI, G. Sazonalidade e soluções nutritivas na miniestaquia de Araucaria angustifolia (Bertol.) Kuntze. Revista Árvore, v. 39, n. 2, p. 283-293, 2015

PIZZATTO, M.: WAGNER JÚNIOR, A : LUCKMANN, D.: PIROLA, K.; CASSOL, D. A. MAZARO, S. M. Influência do uso de AIB, época de coleta e tamanho de estaca na propagação vegetativa de hibisco por estaquia. Revista Ceres, v. 58, n. 4, p. $487-492,2011$

REGENT INSTRUMENTS. User Guide, Mac/WinRHIZO V4 1, Reference, Regent Instruments Inc. Disponível em: https:/regentinstruments.com/assets/ references.html\#winrhizo. Acesso em: 20 de março de 2020.

RIOS, E. S.; PEREIRA, M. D. C. SANTOS, L. D. S.; DE SOUZA, T. C. RIBEIRO, V. G. Concentraç̃es de ácido indolbutírico, comprimento e época de coleta de estacas, na propagação de umbuzeiro. Revista Caatinga, v. 25, n. 1, p. 52-57, 2012

RODRIGUES, M C C. C. Miniestaquia de Plathymenia reticulata Benth em função da posição do propágulo na brotação. 2018 . 47 p. Trabalho de conclusão de curso, Universidade estadual do Norte Fluminense - UENF.

R CORE TEAM. R: A language and environment for statistical computing. $R$ Foundation for Statistical Computing, Vienna, Austria. 2019

SANT'ANA, B. T. Propagação vegetativa de Lecythis spp. por estaquia e miniestaquia. 2017. 44 p. Dissertação de Mestrado Universidade Federal do Espírito Santo - UFES.

SANTOS, G. A. Propagação vegetativa de mogno, cedro rosa, jequitibá rosa e angico vermelho por miniestaquia. 2002. 75 p. Trabalho de Conclusão de Curso Universidade Federal de Viçosa - UFV.

SANTOS, L. C. R. dos. Propagação de guanandi (Calophyllum brasiliense Cambess) por miniestacas inoculadas com microrganismos rizosféricos. 2013. 63 p. Dissertação de Mestrado Instituto federal de educação, ciência e tecnologia goiano.

SILVA, R. L. da; OLIVEIRA, M. L. de; MONTE, M. A.; XAVIER, A. Propagação clonal de guanandi (Calophyllum brasiliense) por miniestaquia. Agronomía Costarricense, v. 34, n. 1, p. 99-104, 2010.

SILVA, R. de D. Miniestaquia de Paratecoma peroba (Record) Kuhlm. capacidade de enraizamento e utilização de brassinosteróide. 2019. 74 f. Dissertação de Mestrado Universidade Estadual do Norte Fluminense - UENF.
SOMAVILLA, T. M. Enraizamento de miniestacas e seleção de Cordia trichotoma (Vellozo) Arrabida ex Steudel para a propagação por miniestaquia. 2018. 90 p. Dissertação de Mestrado Universidade de Santa Maria.

SOUZA, L. S. D. Propagação vegetativa de Tabebuia Aurea (Silva Manso) Benth. \& Hook. F. Ex. S. Moore pela Miniestaquia. 2019. 35 p. Trabalho de conclusão de curso Universidade Federal do Semiárido.

SOUZA, J. S. de; BARROSO, D. G.; SILVA, M. P. S. da; FERREIRA, D. de A GRAVINA, G. de A.; CARNEIRO, J. G. de A. Produtividade de minicepas de cedro australiano e remoção de nutrientes pela coleta sucessiva de miniestacas. Ciência Florestal, v. 24, n. 1, p. 71-77, 2014.

SILVA, M. P. S. da; BARROSO, D. G.; SOUZA, J. S. de; FERREIRA, D. de A CARNEIRO, J. G. de A. Enraizamento de miniestacas e produtividade de minicepas de cedro australiano manejadas em canaletões e tubetes. Ciência Florestal, v. 22, n. 4, p. 703-713, 2012.

TITON, M.; XAVIER, A.; REIS, G. G.; WAGNER, C. O. Eficiência das minicepas e microcepas na produção de propágulos de clones de Eucalyptus grandis. Revista Árvore, v. 27, n. 5, p. 619-625, 2003.

VENABLES, W. N.; RIPLEY, B. D. Modern Applied Statistics with S. Fourth Edition. Springer, New York. ISBN 0-387-95457-0. 2002.

WENDLING I.; FERRARI, M. P.; DUTRA, L. F. Produção de mudas de corticeirado-banhado por miniestaquia a partir de propágulos juvenis. Comunicado Técnico, Colombo n.130, p. 1-5, 2005

WENDLING, I. F. Produção e sobrevivência de miniestacas e minicepas de erva-mate cultivadas em sistema semi-hidropônico. Pesquisa Agropecuária Brasileira, v. 42, n. 2, p. 289-292, 2007

XAVIER, A.; SANTOS, G. A. dos; OLIVEIRA, M. L. de. Enraizamento de miniestaca caulinar e foliar na propagação vegetativa de cedro-rosa (Cedrela fissilis Vell.). Revista Árvore, v. 27, n. 3, p. 351-356, 2003 a

XAVIER, A.; SANTOS, G. A. DOS; WENDLING, I.; OLIVEIRA, M. L. de. Propagação vegetativa de cedro-rosa por miniestaquia. Revista Arvore, v. 27, n. 2, p. 139143,2003 b.

XAVIER, A.; WENDLING, I.; SILVA, R. L. Silvicultura clonal: princípios e técnicas

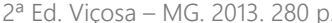

ZIMMERMANN, F. J. P. Estatística aplicada à pesquisa agrícola. Santo Antônio de Goiás: EMBRAPA Arroz e Feijão. 2004. 400 p. 